\title{
Progress in Turbine Machinery
}

\author{
By Eng.-Capt. Edgar C. Smith, o.B.E., R.N.
}

$\mathrm{I}^{\mathrm{N}}$ March 1776 in the reign of George III, Johnson and Boswell spent a few days in Birmingham, and the latter, accompanied by Johnson's old schoolfellow Hector, took the opportunity to see the famous Soho Manufactory of Boulton and Watt. During Boswell's tour through the shops where parts of the engines of Watt were being constructed, Boulton with pardonable pride remarked to him: "Here, Sir, I sell what all the world desires to have-Power". Only half a century had passed since Newcomen, in the reign of George I, by the invention of the atmospheric pumping engine, had ushered in the age of steam power, but already steam engines were being erected in mines, factories, breweries and works on an increasing scale, and five years later Boulton wrote to Watt, "The people of London, Manchester and Birmingham are steam-mill mad". Great pioneers as they were, neither Watt nor Boulton, however, visualised the important part steam was destined to play in industry and transport, or that before the death of George III steam would be applied to ships and locomotives. Year by year the demand for power grew ; by 1840 the steam engines of the world were estimated to have an aggregate of more than 2,000,000 horse-power, and a century after Boulton had spoken of London, Manchester and Birmingham as being steam-mill mad, the total horse power of stationary and marine steam engines and steam locomotives in the world was estimated at about $30,000,000$.

However remarkable these figures may appear, they are comparatively insignificant when placed beside those of the world's power plants to-day. With the passage of time have come improvements in hydraulic turbines, the introduction of oil, gas and spirit engines, the invention of steam turbines and also the construction of power-driven electric generators from which electricity for power purposes can be transmitted over long distances. Any review of the mechanical progress of the reign of H.M. King George $V$ must therefore necessarily have as its central feature the development of prime movers and electric generators. Of the prime movers, the reciprocating steam engine is still the most important unit on our railways, the petrol engine is practically without a rival on the roads and in the air, the oil engine has spread all over the world and has successfully challenged the steam engine for certain classes of ships, the hydraulic turbine coupled to electric generators is used where sufficient water power is available, but for the propulsion of fast vessels, such as warships and liners, and for driving electric generators in steam power houses the steam turbine is supreme. About 96 per cent of the electricity generated in Great Britain is produced in steam stations, the majority of which contain turbogenerators. It is acknowledged that the construction of the first turbo-generator by Parsons in 1884 is as great a landmark in engineering history as the invention of the separate condenser by Watt in 1765 , but it is only within approximately the last twenty-five or thirty years that the steam turbine has surpassed in size and power the great reciprocating engines which were the direct descendants of the rotative engines of Watt.

When shown at the Inventions Exhibition of 1885, the first turbo-generator of Parsons, with its high speed of rotation (18,000 r.p.m.) and its extravagant steam consumption (129 lb. per kilowatt hour) excited no great interest and raised no great hopes. It contained, however, all the essential elements for success, and ten years later Parsons was building his first 350-kilowatt turbogenerator and also the 2,000 h.p. turbines for the famous Turbinia.

Six years later a great advance was made by the construction of the $1,250 \mathrm{kw}$. machines for the city of Elberfeld in Germany. These machines had a steam consumption of only one seventh that of the original turbo-generator, and their success paved the way for further developments. One of the finest and most efficient machines running at the time of the accession of King George $\mathrm{V}$ was a $5,000 \mathrm{kw}$. turbo-generator at the Carville power station of the Newcastle-uponTyne Electric Supply Company. Supplied with steam at a pressure of $200 \mathrm{lb}$. per sq. in. superheated to $508^{\circ} \mathrm{F}$., this machine revolved at 1,200 r.p.m. and had a steam consumption of $13 \cdot 19 \mathrm{lb}$. per kwh. The record set up by this machine was surpassed by that of a far larger turbogenerator of 25,000 kw. ordered in 1911 from Messrs. C. A. Parsons and Co., Ltd., for the Fisk Street Station of the Commonwealth Edison Company of Chicago, U.S.A. In this case the speed was 750 r.p.m., the steam pressure $200 \mathrm{lb}$. per sq. in., the steam temperature $588^{\circ} \mathrm{F}$. and the steam consumption $10.42 \mathrm{lb}$. per $\mathrm{kwh}$. or about one twelfth of the original machine. Ever since then, by improvements in design, the utilisation of many inventions, the employment of superior materials, by increasing steam pressures and temperatures and by many other means, it has been possible to construct turbo-generators still 
more efficient and of greater and greater capacity, the present limit in size being marked by the $208,000 \mathrm{kw}$. machine of the State Line Power Station, Chicago.

In Great Britain, the limit of size is marked by the $105,000 \mathrm{kw}$. turbo-generator now being erected in the Battersea Power Station of the London Power Company by the MetropolitanVickers Electrical Co., Ltd. The installation of such machines is one of the outcomes of the extended use of electricity for industrial and domestic purposes, brought about partly through the work of the Electricity Commissioners and the Central Electricity Board, which have been responsible for the erection of the National Grid. In the latest report of the Central Electricity Board, it is stated that the production of electricity in Great Britain during the past five years has increased by 50 per cent. Co-ordination in the electric supply industry, too, has led to the closing down of uneconomical stations and the erection of many new stations, of which Battersea is but one. Full descriptions of these stations have appeared from time to time in the technical press and from these have been taken a few particulars of turbo-generators which illustrate current practice. In various countries stations have been or are being erected, with steam pressures far in excess of those mentioned below, but these stations are comparatively few.

It was perhaps but natural, as the Parsons steam turbine was developed on the banks of the Tyne, that some of the most historic turbogenerators should be found in the Newcastle area. Mention has already been made of the Carville station. The latest and most up-to-date station in the district is the new Dunston power station of the North-Eastern Electric Supply Company. This station has an ultimate capacity of $300,000 \mathrm{kw}$., but at present it contains three $50,000 \mathrm{kw}$. machines. The steam is supplied at $625 \mathrm{lb}$. per sq. in. and at a temperature of $825^{\circ} \mathrm{F}$. The turbines are of the two-cylinder tandem type and run at 1,500 r.p.m. Current is generated by the alternators at 13,500 volts and a frequency of 50 cycles. An interesting feature is that the steam leaving the high-pressure cylinder is taken at a pressure of $115 \mathrm{lb}$. per sq. in. to re-heaters and is then passed to the low-pressure turbine at a temperature of $800^{\circ} \mathrm{F}$.

One of the most important stations in the Midlands is the Hams Hall station of the Birmingham Corporation, the first part of which was opened by the Duke of York in November 1929. It is designed for an ultimate capacity of $240,000 \mathrm{kw}$. but there is ample room for its expansion to $1,000,000 \mathrm{kw}$. if required. Steam is supplied from pulverised-fuel fired boilers at $375 \mathrm{lb}$. per sq. in. and $710^{\circ} \mathrm{F}$. to $30,000 \mathrm{kw}$. turbo-generators running at 1,500 r.p.m., generating current at 11,000 volts and a frequency of 25 cycles. In the north-west, the Clarence Dock power station of the Liverpool Corporation has the highest thermal efficiency of any station in Great Britain, namely, 26.06 per cent. It is unique in being built on the floor of a disused dock. Designed for an ultimate capacity of $400,000 \mathrm{kw}$., with eight $50,000 \mathrm{kw}$. turbo-generators running at 1,500 r.p.m., it has at present three machines generating current at 7,250 volts and a frequency of 50 cycles. The steam pressure is $450 \mathrm{lb}$. per sq. in. and the steam temperature $750^{\circ} \mathrm{F}$. The station began work in 1931, and tests of the steam-raising plant showed an efficiency of 86.45 per cent, while the thermal efficiency of the turbines was 30.4 per cent. In the construction of the generators, advantage was taken of electric welding. By using welded frames for the stators instead of cast frames, no less than 16 tons weight was saved.

It would be possible to trace the development of power station practice from the power houses in the London district alone, for it was in Holborn in 1882 that the first central station in the Old World was opened, while at Deptford, Ferranti built what has been called the "forerunner of modern power stations". Several big companies to-day serve the metropolitan district, and the London Power Company has six 'selected' stations for the purposes of the Electricity Act of 1926 . Of these, Deptford West took the first place for thermal efficiency among British stations in 1931, while at Battersea is being installed the 105,000 $\mathrm{kw}$. turbo-generator referred to above. The Battersea station is designed for an ultimate capacity of $400,000-500,000 \mathrm{kw}$. The machines at work at the present time consist of two $69,000 \mathrm{kw}$. three-cylinder turbines driving generators delivering current at 11,000 volts. The boiler pressure is $625 \mathrm{lb}$. per sq. in. and the highest temperature of the steam is $875^{\circ}-900^{\circ} \mathrm{F}$. This station is equipped with an elaborate plant for preventing the emission of sulphurous fumes from the chimneys. Lastly, brief mention may be made of the Barking power station of the County of London Electric Supply Co., the first part of which was opened by H.M. the King ten years ago. The largest set at that time was a $35,000 \mathrm{kw}$. turbo-generator, but the station now possesses two $75,000 \mathrm{kw}$. machines using steam at $625 \mathrm{lb}$. pressure and $825^{\circ} \mathrm{F}$. temperature. In these turbines steam is 'bled' from four different points for the purpose of feed heating. The station has at present a capacity of $390,000 \mathrm{kw}$.

From the first, the steam turbine had one particular advantage over the reciprocating engine for driving electric generators, inasmuch as it was 
most efficient at high speeds. When, however, it was applied to marine propulsion, owing to the inefficiency of propellers at high speeds, a compromise had to be made. Yet its inherent qualities led the marine steam turbine quickly to surpass the turbo-generator in point of size, and only ten years elapsed between the debut of the Turbinia at the Diamond Jubilee review of 1897 and the construction of the 70,000 h.p. turbines of the Lusitania and Mauretania and the adoption of steam turbines for all classes of warships except submarines. When referring to the steam turbine in his Gray Lecture to the Institution of Mechanical Engineers in 1930, Eng. Vice-Admiral Skelton said : "Its application is one of the few important marine changes which were made without any setback, and the initial success and the rapid extension of the system is undoubtedly attributable to the experience gained in its long and gradual development under proper conditions on shore, no less than to the soundness of the conceptions of the inventor and his thorough exploratory work in connexion with the marine application".

It had been realised quite early that in ships it would be an advantage to have some form of reduction gear between the turbine and the propeller, and the development of steam turbines afloat during the last twenty-five years presents several aspects, first the progress with direct driving turbines, secondly the use of turbines coupled to the propeller shafts with either mechanical, hydraulic or electric transmission gear and thirdly the combined use of reciprocating engines and turbines. The most notable directdriven turbine ships of the last quarter of a century include the Aquitania (62,000 h.p.), Berengaria
$(65,000$ h.p. $)$, Majestic $(84,000$ h.p. $)$ and the Leviathan (82,000 h.p.) ; and large warships such as the Iron Duke (31,000 h.p.), Malaya (75,000 h.p.) and Repulse (112,000 h.p.). Helical-toothed reduction gear, tried out by Parsons in the Vespasian in 1909, was adopted in turbine-driven crosschannel vessels and destroyers in 1911 and quickly came into favour. By September 1919 the total horse-power of geared marine turbines completed or under construction was about $18,000,000$. The use of gearing enabled the efficiency of both turbines and propellers to be increased, turbines of 20,000 h.p. with gearing being equal to turbines of 30,000 h.p. without gearing. H.M.S. Furious (90,000 h.p.), H.M.S. Hood (144,000 h.p.) and H.M.S. Nelson $\mathbf{( 4 5 , 0 0 0}$ h.p.) all have geared turbines, as also have the modern Atlantic liners Bremen, Europa, Conte di Savoia and Rex, while the machinery of the Queen Mary will be of this type.

Hydraulic transmission between the turbine and the propeller has never been extensively used, but electrical transmission, first used on a large scale in the United States Navy, has made rapid strides. The French liner Normandie is fitted with electric drive, and will have four main turbo-generators of $34,200 \mathrm{kw}$. delivering current to the motors on the propeller shafts, the whole plant rivalling in size and interest the machinery of a big power station.

Marine enginecring practice has sometimes forged ahead of and sometimes lagged behind land practice, but to-day it tends to run on parallel lines. Progress during the last twenty-five years has been due to many eminent engineers, among whom the inventors of steam turbines, such as Parsons, De Laval, Curtis, Zoelly and Rateau, hold the place of honour.

\section{News and Views}

\section{Prof. P. Kapitza and the U.S.S.R.}

IT is common knowledge in scientific circles that Prof. P. Kapitza, director of the Royal Society Mond Laboratory at Cambridge, and Messel professor of the Royal Society, has been detained in Russia since last September by order of the Government of the U.S.S.R. Kapitza came to England as a member of a Russian scientific commission in 1921. He soon started to work as a research student at Cambridge under the supervision of Lord Rutherford, and after some preliminary work on radioactivity he commenced work on the production of intense magnetic fields, and in 1925 a new laboratory, financed by the Department of Scientific and Industrial Research, was opened for the work. By the use of a special alternator, Kapitza was able to produce fields up to 300,000 gauss, and to carry out experiments showing the existence of new phenomena in conduction and in magneto-striction. Since most of these phenomena are more pronounced at low temperatures, a hydrogen liquefaction plant was added in 1929, and in 1930 the Royal Society made a special donation of $£ 15,000$ to enable a new laboratory to be built to house the original apparatus, together with a helium liquefaction plant. It was characteristic of Kapitza that he was not satisfied to take over existing designs of helium liquefiers, but began immediately to work on the construction of a new type of liquefier which required no liquid hydrogen. This liquefier is an illustration of Kapitza's special technical gift, for it incorporates a piston type engine, which works down to the temperature of liquid helium. This liquefier, which was described in Nature of May 12, 1934 (p. 708), was perfected last summer, and Kapitza was able to carry out preliminary experiments using strong magnetic fields combined with helium temperatures before leaving for Russia in September to attend the Mendeléeff Congress. 